\title{
Bacteriological Profile in Endoscopic Urology: Urology A Departement Experience Over 6 Months
}

Dergamoun Hamza ${ }^{*}$, Abdallah Hussein, ZIANI Idriss, Hachem Al Sayegh, Benslimane Lounis, Nouini Yassine

Service d'Urologie A, Centre Hospitalier Universitaire Ibn Sina

DOI: $10.36347 /$ sasjm.2020.v06i04.002

| Received: 22.03.2020 | Accepted: 30.03.2020 | Published: 07.04.2020

*Corresponding author: Dergamoun Hamza

Abstract

Original Research Article

This work is a retrospective study that took 6 months from january 1 st 2019 to june 31 st 2019. It included 200 patients from Urology A and B departments in the IBN SINA hospital RABAT that undertoo an endoscopic urology intervention. The objective of this work is to describe the bacteriological profile of the preoperative urinary infection within these patients. The median age of our study is 61 years old, with the extremes of 16 and 93 . The males were highly predominant with a sexe ratio of 4,8 . Smoking is the most found antecedent with a percentage of $38 \%$, followed by hypertension (18\%) and diabetes (11\%). The TURB was the most executed endoscopic gesture with a percentage of $36 \%$, followed by the TURP $(28 \%)$ and the instalment or changing of a double J stent $(17 \%) .53,5 \%$ of the CBUE were positive with a germ identified, gram negative bacilli were the dominant ones with a percentage of $83,8 \%$, E.Coli is the germ most commonly found in urinary infections $(53,2 \%)$ followed by Klebsiella with $10,2 \%$ and then enterobacteroclocae and staphylococcus with the same percentage of $8,5 \%$ each.

Keywords: Bacteriological profile, endoscopy, antibiotics.

Copyright @ 2020: This is an open-access article distributed under the terms of the Creative Commons Attribution license which permits unrestricted use, distribution, and reproduction in any medium for non-commercial use (NonCommercial, or CC-BY-NC) provided the original author and source are credited.

\section{INTRODUCTION}

The urinary system is physiologically a sterile site, but colonization or infection of different parts of the system is quite common, due indications of surgical treatment, or urinary drainage.

The execution of a surgical gesture on infected urines led before to a high incidence of perioperative infections, leading to an elevated morbidity and mortality. The realization of this risk as well as preoperative systematic urine sterilization, when possible, is probably one of the biggest developments of this field.

This work made by Urology a department of the IBN SINA hospital in RABAT, will report the bacteriological profile of pre-operative urinary infections in endoscopic urology.

The purpose of our work is

To know the germs accountable for urinary infections of these patients

To know their antibiotic sensitivity

\section{Equipement and process}

It's a retrospective study that took 6 months from january 1 st 2019 to june 31st 2019. It included
200 patients from Urology a department in the IBN SINA hospital RABAT, who undertook an endoscopic urology intervention.

We have studied their epidemiologic features : age, sexe, antecedents, executed gestures, clinical signs of urinary infection, results of preoperative cytobacteriological urine examination (CBUE) as part of the preanesthesic assessment (direct examination, culture and antibiogram), preoperative antibiotherapy, bladder drainage, cystostomy or nephrostomy as well as the duration of their instalment, antibiotherapy, or perioperativee antibioprophylaxis.

The data exploration of each result and file was analysed through a pre-established data sheet (Annex $1)$.

\section{RESULTS}

\section{Epidemiologic profile of the studied population}

The median age of our patients was 61 years old, with extremes of 16 and 93 years old.

166 patients were men ( $83 \%$ of the cases) and 34 were women (17\% of the cases) with a sex ratio male/female of 4,8 . 
$38 \%$ of our patients were smokers, $13.5 \%$ with a hypertension, $11 \%$ with diabetes, and $5 \%$ had a cardiopathy.

\section{Intervention type}

Table-1: Distribution by intervention type

\begin{tabular}{|c|c|c|}
\hline Intervention type & number & \% \\
\hline TURB & 72 & 36 \\
\hline TURP & 56 & 28 \\
\hline Placement or change of double J stent & 34 & 17 \\
\hline Uretrotomy & 19 & 9.5 \\
\hline Ureteroscopy & 11 & 5.5 \\
\hline cystoscopy & 8 & 4 \\
\hline
\end{tabular}

\section{C-Incidence of microorganisms}

On 200 UCBE executed before the surgical gesture, 107 were positive with a germ identification (53.5\%). 43 cases had a positive leukocyturia without bacteriuria $(21.5 \%)$ and 3 UCBE were polymorphous (1.5\%).

\section{D-Isolatedgerms}

Table-2: Distribution by isolatedgerms

\begin{tabular}{|c|c|c|c|}
\hline Gram NegativeBacilli & Germ & Number & percentage \\
\cline { 2 - 4 } & E.Coli & 57 & $53.2 \%$ \\
\cline { 2 - 4 } & Klebsiella & 11 & $10.2 \%$ \\
\cline { 2 - 4 } & P.Aerugenosa & 7 & $6.5 \%$ \\
\cline { 2 - 4 } & Enterobactercloacae & 9 & $8.4 \%$ \\
\cline { 2 - 4 } & Serratia & 4 & $3.7 \%$ \\
\cline { 2 - 4 } & Proteus mirabilis & 2 & $1.8 \%$ \\
\hline Gram Positive Cocci & Staphylococcus & 9 & $8.4 \%$ \\
\cline { 2 - 4 } & Streptococcus & 3 & $2.8 \%$ \\
\cline { 2 - 4 } & Enterococcusfeacalis & 4 & $3.7 \%$ \\
\hline Gram NegativeCocci & AcinetobacterBaumani & 1 & $0.9 \%$ \\
\hline & Total & 107 & $100 \%$ \\
\hline
\end{tabular}

\section{E-sensitivity profile of different microorganisms}

The bacteriologic profile of Echerchia Coli: (57 UCBE)

\begin{tabular}{|c|c|c|c|c|c|c|c|c|}
\hline \multirow{2}{*}{ Antibiotic } & \multicolumn{2}{|c|}{ Sensitive } & \multicolumn{2}{c|}{ Resistant } & \multicolumn{2}{c|}{ Intermediate } & \multicolumn{2}{c|}{ Untested } \\
\cline { 2 - 10 } & Nmbr & $\mathbf{\%}$ & Nmbr & $\mathbf{\%}$ & Nmbr & $\mathbf{\%}$ & Nmbr & $\%$ \\
\hline Amikacin & 56 & 98,3 & 0 & 0 & 1 & 1,7 & 0 & 0 \\
\hline Genta & 45 & 78,9 & 11 & 19,2 & 0 & 0 & 1 & 1,7 \\
\hline Ertapenem & 57 & 100 & 0 & 0 & 0 & 0 & 0 & 0 \\
\hline Imipenem & 57 & 100 & 0 & 0 & 0 & 0 & 0 & 0 \\
\hline Cephalotin & 4 & 7 & 27 & 47,3 & 26 & 45,6 & 0 & 0 \\
\hline Cefoxitin & 45 & 78,9 & 2 & 3,5 & 0 & 0 & 10 & 17,5 \\
\hline Cefixime & 52 & 91,2 & 5 & 8,7 & 0 & 0 & 0 & 0 \\
\hline Ceftazidime & 51 & 89,4 & 6 & 10,5 & 0 & 0 & 0 & 0 \\
\hline Ceftriaxone & 52 & 91,2 & 5 & 8,8 & 0 & 0 & 0 & 0 \\
\hline cefipime & 52 & 91,2 & 5 & 8,8 & 0 & 0 & 0 & 0 \\
\hline Ampicillin & 17 & 29,8 & 40 & 70,2 & 0 & 0 & 0 & 0 \\
\hline Ticarcillin & 17 & 29,8 & 40 & 70,2 & 0 & 0 & 0 & 0 \\
\hline Amox-clav & 20 & 35 & 37 & 65 & 0 & 0 & 0 & 0 \\
\hline Ticar-clav & 21 & 36,8 & 36 & 63,2 & 0 & 0 & 0 & 0 \\
\hline Pipé -tazo & 52 & 91,2 & 5 & 8,8 & 0 & 0 & 0 & 0 \\
\hline Trim-sulf & 32 & 56,1 & 25 & 43,9 & 0 & 0 & 0 & 0 \\
\hline fosfomycin & 56 & 98,2 & 1 & 1,8 & 0 & 0 & 0 & 0 \\
\hline Nitrofurantoin & 56 & 98,2 & 1 & 1,8 & 0 & 0 & 0 & 0 \\
\hline ciprofloxacin & 27 & 47,3 & 30 & 42,7 & 0 & 0 & 0 & 0 \\
\hline Norfloxacin & 29 & 50,8 & 28 & 49,2 & 0 & 0 & 0 & 0 \\
\hline Nalidixicacid & 25 & 43,8 & 32 & 46,2 & 0 & 0 & 0 & 0 \\
\hline
\end{tabular}


B-Bacteriologic profile of Klebsiella P: (11 UCBE)

\begin{tabular}{|c|c|c|c|c|c|c|c|c|}
\hline \multirow{2}{*}{ Antibiotic } & \multicolumn{2}{|c|}{ sensitive } & \multicolumn{2}{c|}{ resistant } & intermediate & \multicolumn{2}{c|}{ Untested } \\
\cline { 2 - 10 } & $\mathbf{n m b r}$ & $\mathbf{\%}$ & $\mathbf{n m b r}$ & $\mathbf{\%}$ & $\mathbf{n m b r}$ & $\mathbf{\%}$ & $\mathbf{n m b r}$ & $\mathbf{\%}$ \\
\hline Amikacin & 9 & 81,8 & 0 & 0 & 1 & 9 & 1 & 9 \\
\hline Genta & 8 & 72,7 & 2 & 18,1 & 0 & 0 & 0 & 0 \\
\hline Ertapenem & 8 & 72,7 & 0 & 0 & 1 & 9 & 2 & 18,1 \\
\hline Imipenem & 10 & 90,9 & 0 & 0 & 0 & 0 & 1 & 9 \\
\hline cephalotin & 2 & 18,1 & 7 & 63,6 & 0 & 0 & 2 & 18,1 \\
\hline Ceftazidime & 5 & 45,4 & 5 & 45,4 & 1 & 9 & 0 & 0 \\
\hline Ceftriaxone & 6 & 54,5 & 3 & 27,2 & 0 & 0 & 2 & 18,1 \\
\hline Cefipime & 4 & 36,3 & 5 & 45,4 & 0 & 0 & 2 & 18,1 \\
\hline Ampicillin & 0 & 0 & 11 & 100 & 0 & 0 & 0 & 0 \\
\hline Ticarcillin & 0 & 0 & 10 & 90,9 & 0 & 0 & 1 & 9 \\
\hline Amox-clav & 0 & 0 & 11 & 100 & 0 & 0 & 0 & 0 \\
\hline Ticar-clav & 2 & 18,1 & 8 & 72,7 & 0 & 0 & 1 & 9 \\
\hline Pipe-tazo & 3 & 27,2 & 4 & 36,3 & 0 & 0 & 4 & 36,3 \\
\hline Bactrim & 4 & 36,3 & 6 & 54,5 & 0 & 0 & 1 & 9 \\
\hline Ciprofloxacin & 5 & 45,4 & 5 & 45,4 & 0 & 0 & 1 & 9 \\
\hline Norfloxacin & 5 & 45,4 & 5 & 45,4 & 0 & 0 & 1 & 9 \\
\hline
\end{tabular}

C-Bacteriologic profileof Pseudomonas Aerugenosa:(7 UCBE)

\begin{tabular}{|c|c|c|c|c|c|c|c|c|}
\hline \multirow{2}{*}{ ATB } & \multicolumn{2}{|c|}{ sensitive } & \multicolumn{2}{c|}{ resistant } & \multicolumn{2}{c|}{ intermediate } & \multicolumn{2}{c|}{ Untested } \\
\cline { 2 - 9 } & nmbr & $\%$ & nmbr & $\%$ & nmbr & $\%$ & nmbr & $\%$ \\
\hline tobramycin & 3 & 42,8 & 3 & 42,8 & 0 & 0 & 1 & 14,2 \\
\hline amikacin & 6 & 85,7 & 1 & 14,2 & 0 & 0 & 0 & 0 \\
\hline Genta & 5 & 71,4 & 2 & 28,5 & 0 & 0 & 0 & 0 \\
\hline imipenem & 4 & 57,1 & 1 & 14,2 & 2 & 28,5 & 0 & 0 \\
\hline ceftazidime & 5 & 71,4 & 2 & 28,5 & 0 & 0 & 0 & 0 \\
\hline Cefepime & 5 & 71,4 & 2 & 28,5 & 0 & 0 & 0 & 0 \\
\hline Ticarcillin & 2 & 28,5 & 5 & 71,4 & 0 & 0 & 0 & 0 \\
\hline Ticar-clav & 1 & 14,2 & 4 & 57,1 & 0 & 0 & 3 & 42,8 \\
\hline Piperacillin & 2 & 28,5 & 4 & 57,1 & 0 & 0 & 1 & 14,2 \\
\hline Pipe-tazo & 3 & 42,8 & 3 & 42,8 & 0 & 0 & 1 & 14,2 \\
\hline bactrim & 0 & 0 & 6 & 85,7 & 0 & 0 & 1 & 14,2 \\
\hline Ciprofloxacin & 1 & 14,2 & 3 & 42,8 & 2 & 28,5 & 1 & 14,2 \\
\hline Levofloxacin & 1 & 14,2 & 3 & 42,8 & 0 & 0 & 3 & 42,8 \\
\hline colistin & 5 & 71,4 & 1 & 14,2 & 0 & 0 & 1 & 14,2 \\
\hline
\end{tabular}

D-bacteriologic profileof staphylococcus: (9 UCBE)

\begin{tabular}{|c|c|c|c|c|c|c|}
\hline \multirow{2}{*}{ Antibiotic } & \multicolumn{2}{|c|}{ sensitive } & \multicolumn{2}{c|}{ resistant } & \multicolumn{2}{c|}{ Untested } \\
\cline { 2 - 7 } & $\mathbf{n m b r}$ & $\mathbf{\%}$ & $\mathbf{n m b r}$ & $\mathbf{\%}$ & $\mathbf{n m b r}$ & $\mathbf{\%}$ \\
\hline Tobramycin & 6 & 66,6 & 2 & 22,2 & 1 & 11,1 \\
\hline Gentamycin & 7 & 77,7 & 2 & 22,2 & 0 & 0 \\
\hline Vancomycin & 9 & 100 & 0 & 0 & 0 & 0 \\
\hline Teicoplanine & 8 & 88,8 & 0 & 0 & 1 & 11,1 \\
\hline Clindamycin & 8 & 88,8 & 1 & 11,1 & 0 & 0 \\
\hline Erythromycin & 6 & 66,6 & 3 & 33,3 & 0 & 0 \\
\hline Daptomycin & 7 & 77,7 & 0 & 0 & 2 & 22,2 \\
\hline PeniG & 1 & 11,1 & 7 & 77,7 & 1 & 11,1 \\
\hline Oxacillin & 5 & 55,5 & 4 & 44,4 & 0 & 0 \\
\hline Fucidicacid & 2 & 22,2 & 7 & 77,7 & 0 & 0 \\
\hline Levofloxacin & 2 & 22,2 & 5 & 55,5 & 2 & 22,2 \\
\hline Bactrim & 6 & 66,6 & 1 & 11,1 & 2 & 22,2 \\
\hline fosfomycin & 6 & 66,6 & 2 & 22,2 & 1 & 11,1 \\
\hline
\end{tabular}


E-bacteriologic profileof Enterobactercloacae: (9 UCBE)

\begin{tabular}{|c|c|c|c|c|}
\hline \multirow{2}{*}{ Antibiotic } & \multicolumn{2}{|c|}{ sensitive } & \multicolumn{2}{c|}{ resistant } \\
\cline { 2 - 5 } & $\mathbf{n m b r}$ & $\mathbf{\%}$ & $\mathbf{n m b r}$ & $\mathbf{\%}$ \\
\hline Amiklin & 9 & 100 & 0 & 0 \\
\hline Genta & 8 & 88,8 & 1 & 11,2 \\
\hline Ertapenem & 9 & 100 & 0 & 0 \\
\hline Emipeneme & 9 & 100 & 0 & 0 \\
\hline Cephalotin & 0 & 0 & 9 & 100 \\
\hline Cefixime & 6 & 66,6 & 3 & 33,3 \\
\hline Ceftazidime & 6 & 66,6 & 3 & 33,3 \\
\hline Ceftriaxone & 6 & 66,6 & 3 & 33,3 \\
\hline Cefepime & 6 & 66,6 & 3 & 33,3 \\
\hline Ampicillin & 0 & 0 & 9 & 100 \\
\hline Ticarcillin & 6 & 66,6 & 3 & 33,3 \\
\hline Amox-clav & 0 & 0 & 9 & 100 \\
\hline Ticar-clav & 6 & 66,6 & 3 & 33,3 \\
\hline Pipé-tazo & 7 & 77,7 & 2 & 28,5 \\
\hline Bactrim & 6 & 66,6 & 3 & 33,3 \\
\hline Ciprofloxacin & 5 & 55,5 & 4 & 44,5 \\
\hline Norfloxacin & 5 & 55,5 & 4 & 44,5 \\
\hline Nalidixicacid & 5 & 55,5 & 4 & 44,5 \\
\hline
\end{tabular}

\section{DISCUSSION}

The execution of a surgical gesture on infected urines led before to a high incidence of perioperative infections, leading to an elevated morbidity and mortality. The realization of this risk as well as preoperative systematic urine sterilization, when possible, is probably one of the biggest developments of this field.

\section{EPIDEMIOLOGY}

On sterile urine, and aside from its indication for obstructive pyelonephritis, nephrostomies expose the patient to a septic risk comparable to that of cysctoscopies, meaning less than $5 \%$.However, in case of preexisting infection [1], cystoscopy causes bacteraemia in 15 to $20 \%$ of the cases.

The risk linked to the setup of endo-ureteral prosthesis (ureteral catheters, double $\mathbf{J}$ stent) is poorly known.In 2002, Kehinde et al. showed that the risk of bacteriuria and the colonization of the double $\mathrm{J}$ stent, increases with the duration of the catheterization and that it is more important for females or patients with diabetes or chronic kidney failure [2].

A recent meta-analysis showed that the resort to antiobioprophylaxis during a TURP lowers the postoperative bacteriuria from 26 to $9,1 \%$ and septicemia from $4,4 \%$ to $0,7 \%$.Moreover, the mortality linked to a severe sepsis after a TURP, with a sterile preoperative cytobacteriological urine test, is $0.1 \%$ [3].

For the TURP, the 3 main factors recognized in the promotion of postoperative infections are: urinary drainage, preoperative bacteriuria, and no antibioprophylaxis.

\section{Ii-therapeutic attitude}

The screening and the systematic treatment of a preoperative urinary tract infection are now a common practice, they decrease the perioperative morbidity.

\section{II-1-Infected preoperative urine}

It can either be an asymptomatic bacteriuria or a parenchymal infection.

\section{Asymptomatic bacteriuria}

It is extremely frequent in patients with a urinary drainage (vesical catheter, sus-pubic catheter, nephrostomy tube) and even with a detection threshold of $10^{2}$ UFC ml ${ }^{-1}$, many teams still take it into consideration because $95 \%$ of untreated patients, if catheterized, will develop in 24 to $72 \mathrm{~h}$ a bacteriuria greater than $10^{5}$ UFC $\mathrm{ml}^{-1}$.[37] a leukocyturia of $10^{2}$ to $10^{5}$ cells $\mathrm{mm}^{-3}$ [4] is present in $85 \%$ to $90 \%$ of infections on a catheter, but it is not mandatory for the diagnosis $[4,5]$.

The risk of bacteriuria in catheterized patients increases linearly with the duration of the vesical catheterization from 3 to $8 \%$ per day during the first 10 days [59]. After a month of the vesical catheterization, the prevalence of the bacteriuria is practically $100 \%$ [6]. Although it's not generally recommanded to treat an asymptomatic bacteriuria with antibiotics because it promotes the emergence of resistance, in a surgical context, the sterilization of urines with an adapted preoperative antiobiotherapy is a commonly adopted attitude by different teams [3]. The surgical gesture should be framed with a curative antiobiotherapy, usually a monotherapy adapted to the isolated germ in a cytobacteriological urine test done as closely as possible to the intervention [7]. The main objective is to obtain sterile urine in the 48 hours prior to the intervention 
The most commonly found germs are: enterobacteria (E. coli, Klebsiella, Proteus Mirabilis...), entrococcus, staphylococcus, (especially S. epidermidis). The surgery is only allowed if the control CBUE is negative (germ detection). The antibiotherapy is then continued after the intervention until the catheter is removed.

\section{Parenchymal infections}

A fever as well as hyperleukocytosis in a patient with a positive CBUE should evoke a parenchymal infection (pyelonephritis or prostatitis or Epididymoorchitis for male patients).

Aside from an emergency urologic surgery (obstacle removal, abscess) parenchymal infection will be medically treated before surgery for 2 to 3 weeks. The intervention can't be performed unless the urine is sterile and the treatment duration is respected. Antibiotherapy will be continued after surgery for a duration that depends on the etiology and the presumed efficiency of the surgical gesture on the infection cause. For example, patients who have a prostatitis with an acute urinary retention who need to undergo a TURP should benefit from an adapted antibiotic treatment during 3 weeks minimum before surgery. The emergency bladder drainage will be performed with a sus-pubic catheter. The perioperative samples' culture (fragments, adenoma) is possible; it allows an eventual antiobiotherapy adaptation in case of septic complications after intervention [8].

Concerning kidney stone surgery, the isolated germs in the urine could be different from the germs colonizing the calculi. The postoperative antibiotherapy should then be adapted to the germs found in the culture of the stones [9].

\section{II-2-Sterile preoperative urine}

An antibioprophylaxis will be prescribed mainly for interventions including the opening of hollow viscera, especially those normally colonized by commensal bacteria such as the genital tract and the lower urinary system.

However, a sterile CBUE can't formally rule out a urinary infection upstream a complete obstacle. The perioperative bacteriological samples will redress the diagnosis and will allow an adaptation of the antibiotic treatment.

The benefit of antibioprophylaxis around the lower urinary system surgery was brought up in a multitude of studies, with contradictory results [10].

Concerning the TURP, the benefit of antibioprophylaxis is proved [2]. The choice of the antibiotic used should consider the presence, in 27 to $40 \%$ of the cases, of gram positive cocci especially enterococcus isolated in postoperative infectious complications [11].

The factors implicated in this risk elevation aren't totally elaborated but can include an endogenous colonization of the lower urinary system, the uncontrolled use of antibiotics such as cephalosporins and extended bladder drainage.

A consensus seems to be reached in favor of a short duration antibioprophylaxis [12]. It suggests covering the perioperative period by a second generation cephalosporin (cefuroxime or cefamandole $1.5 \mathrm{~g}$ in a single preoperative intake). These recommandations are appliable for vesical tumors resection as well as endoscopic treatment of kidney and ureteral calculi.

The periodic evaluation of the bacterial ecosystem of the department, allows, if necessary, to change the antibiotic used. The consensus conference of 1999 about perioperative antibioprophylaxis concluded that extracorporeal lithortipsy, cystoscopy or urethral fibroscopy, urinary incontinence surgery and clean scrotal surgery don't need an antiobioprophylaxis. Concerning open surgery, a total cystecomy is an indication of antiobioprophylaxis similar to that of Altemier stage II abdominal surgery. For radical prostatectomy and nephrectomy; the antibioprophylaxis isn't advised [12].

\section{III-Germs responsible of urinary infections:}

Many studies have shown the predominance of gram negative bacilli in nosocomial urinary infections: $63.6 \%$ for Hally and Coll [13], 48\% for Stamm and coll [14], 74\% for Krieger and coll [15], 56\% for Platt and coll and 84, 5\% for Yao [16].

In our study, we have found $83.8 \%$ of gram negative bacilli. E.coli is the germ most commonly found in nosoocomial infections. Stam and Coll [14] found $38,6 \%, 30,7 \%$ from the american study N.N.I.S [17] and Yopi Abidjan [18] found 31, 7\%.

In our study, E. coli was found in $53.2 \%$ of the cases, in second place comes Klebsiella with $10.2 \%$ and then enterbactercloacae and staphylococcus with $8.5 \%$ and $8.4 \%$ respectively.

\section{CONCLUSION}

The urinary system surgery concerns older and older patients, prostate surgery covers older patients with a susceptibility to have a preexisting cardiovascular or respiratory disease.

The infectious risk is as important to consider because its a clean but contaminated surgery that needs a urine sterilization before an intervention and also the use of antibioprophylaxis. All that is due to the high 
Dergamoun Hamza et al., SAS J Med, April, 2020; 6(4): 119-125

risk of peri and postoperative bacteremia (as well as the risk of pyelonephritis) during instrumental gestures.

In the preoperative phase, the screening and systematic treatment of urinary infections way before the intervention is used with an objective of having steril urine $48 \mathrm{~h}$ before the gesture.

If preoperative urine is infected: peri and postoperative antibiotherapy.
If preoperative urine is sterile: antibioprophylaxis in urology depending on the protocols.

Our work had a goal to identify the different bacterial species responsible of urinary infections in endoscopic urology.

And also to study their sensitivity and resistance profile to commonly used antibiotics.

Annex

\section{BACTERIOLOGICAL PROFILE IN ENDOSCOPIC UROLOGY} PATIENT SHEET $\quad \mathbf{N}^{\circ}$ :

I-Identity:

-Name:

-Age:

-Sexe:

-ATCDs:

-ASA:

II-Preoperative CBUE:

-Aspect:

-Color:

-Direct examination:

-Leukocytes:

-Culture:

-Red blood cells:

-Antibiogram:

-PH:

III-Risk factors

-urinary drainge:

-Nephrostomy:

-Cystostomy:

-double J stent:

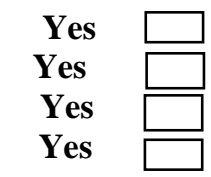

No

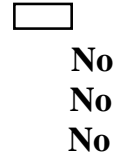

Yes

TURB

Cystoscopy

IV-Prior antibiotherapy:

V- Urologic gesture:

TURP

\section{URETEROSCOPY}

\section{REFERENCES}

1. Knopf HJ, Weib P, Schäfer W, Funke PJ. Nosocomial infections after transurethral prostatectomy. European urology. 1999;36(3):20712.

2. Wang AJ, Bhayani SB. Robotic partial nephrectomy versus laparoscopic partial nephrectomy for renal cell carcinoma: singlesurgeon analysis of $>100$ consecutive procedures. Urology. 2009 Feb 1;73(2):306-10.

3. Berry A, Barratt A. Prophylatic antibiotic use in transurethral prostatic resection: a meta-analysis. The Journal of urology. 2002 Feb 1;167(2):571-7.

4. Andriole GL, Crawford ED, Grubb III RL, Buys SS, Chia D, Church TR, Fouad MN, Gelmann EP, Kvale PA, Reding DJ, Weissfeld JL. Mortality results from a randomized prostate-cancer

\section{JJ}

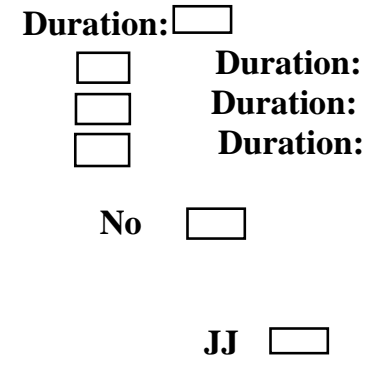

\section{Urethrotomy}

screening trial. New England Journal of Medicine. 2009 Mar 26;360(13):1310-9.

5. Leibovitch I, Foster RS, Wass JL, Rowland RG, Bihrle R, Little SJ, Kopecky KK, Donohue JP. Color Doppler flow imaging for deep venous thrombosis screening in patients undergoing pelvic lymphadenectomy and radical retropubic prostatectomy for prostatic carcinoma. The Journal of urology. 1995 Jun;153(6):1866-9.

6. Anesthesieambulatoire. Recommendations pour la pratique clinique. Les blocs peripheriques des membres chez l'adulte. Sfar; 2013.

7. Cent recommandations pour la surveillance et les préventions des infections nosocomiales. Bull epedemiolhebd; 1992

8. Mathieu R. tumeur du rein. Preventionnephronique. Progurol; 2009. 
9. Prevention de la maladie thromboembolique veineuse perioperatoire et obstetricale.in : recommandation pour la pratique clinique; 2005.

10. Guillonneaub. Vallancieng. Laparoscopic radical prostatectomy: the montsourisexperience. Jurol. 2000

11. Dotyjm. Effect of increased renal parenchymal pressure on renal function. J trauma;1999/

12. Lettre circulaire dh/em 1 n98-7990du 4 aout 1998 relative à la securité d'utilisation des dispositifs medicaux; solutions d'irrigation sterile à base de glycocoll1.5\%.bulletin officiel de santé.1998

13. Halley G l'antibiotherapie des infections nosocomiales rev.part.40, 1990: 817-822

14. Stamm W. Nosocomial infection of the urinary tract. Am; J.Med.70.1981:651-654.
15. Kriger G. Laboratory technique for detection of urinary tract infection. Am. J. Med, sppl 28,1983:78-79

16. Yao A. Contribution de l'evaluation des infections nosocomiales au CHU de Treicheville. Experience de 3 services: Chirurgie, medecine interne et gynecologiethese de medecine Abidjan. 1996,73

17. Khourys, Chatelain C, Pechere JC, bocon- girod L, Richand C. Urologie: pathologie infectieuse et parasitaire. paris: Masson. 1985 :400-448

18. Yapi A. A propos des infections nosocomiales à bacilles gram negatif: Strategieet approche therapeutiques en zone africaine. These de med. 1997,61 